\title{
Development of Entrepreneurial Skills through Vocational Education and Information and Communication Technology (I.C.T) in Nigeria
}

\author{
Okurumeh, Ejedafeta Ashigo \\ Mathematics Department, College of Education, Warr
}

\begin{abstract}
The pace of change brought about by new technologies has had a significant effect on the way people live, work, and play worldwide. New and emerging technologies challenge the traditional process of doing many things including skills acquisition. This paper therefore examines ways of developing entrepreneurial skills and vocational education in Information and Communication Technology (ICT) as it is one of the emerging technologies for employment generation. In the process, the meaning of the concepts entrepreneur, entrepreneurship education, and information and communication technology was explained. It also identified some challenges and strategies for effective entrepreneurship education and benefits of entrepreneurship education in ICT. The paper concluded that government should give adequate attention to entrepreneurial development in the country through the provision of good economic environment especially by promoting vocational education skills in ICT that has the potentials of reducing if not eradicate unemployment and poverty in Nigeria.
\end{abstract}

Keywords: Entrepreneur, Information and Communication Technology, skills, vocational education

\section{Introduction}

The rapid changes in information and communication technology (ICT) can help in reducing if not eradicate completely the social and economic problems caused by many factors in a developing country like Nigeria. ICT offers opportunities for both young and old for learning skills and gaining employment. Aragba-Akpore (1999) noted that of all the technical changes that have influence our lives in recent years, it is information technology which have had the greatest impact. This will continue to be so, at least until the end of the first half of the next century, when other major technological break-through in the areas of new materials, biotechnology or energy may force entirely new ways of living on mankind.

The essence of vocational education is the development of vocational skills that would enable its recipients to be gainfully employed. This forms part of entrepreneurship that exists in the fabric of vocational education. The need for entrepreneurship education started emerging in the mid 1980s. This is because before this period, unemployment and poverty were not a national concern, as it is currently. However, political instability and inconsistencies in the social-economic policies of successive governments led to the emergence of high level ofyouthunemployment inNigeria which the central bank of Nigeria reported to be around $80 \%$.

The Federal Government of Nigeria recently launched a new curriculum known as the Basic Education Curriculum for primary and secondary schools. The new curriculum is said to address amongst other things, issues of value reorientation, poverty eradication, critical thinking and entrepreneurship and life skills. It also allows and gives opportunity for students to be taught skills and educate them on the need to appreciate culture along with Information and communication technology (ICT) that has been introduced into the curriculum to build the child for the future.(NPE, 2015).

\section{Who is an Entrepreneur?}

Entrepreneur comes from the French word entrepredre, which means to undertake, an individual who undertakes an industrial or commercial activity involving financial risks and skills for the purposes of making profits. Meredith (1983) defined an entrepreneur as a person or persons who possesses the ability to recognize and evaluate business opportunities, assemble the necessary resources to take advantage of them and take appropriate action to ensure success. Entrepreneur can be coined as an innovating individual who has developed an ongoing business activity where none existed before.

\section{Entrepreneurship Education}

According to Fafunwa (1985) the genesis of vocational education was the attempt at making education to be relevant to all socio-economic realities of the nation and immediate community. Anthony, Saidu,; Mohammed,. And Junguru, (2009) said that entrepreneurship education is the education that provides training, experience and skills that are suitable for entrepreneurial endeavours'. Hence, entrepreneurship education prepares the individual with entrepreneurial knowledge, competence and skills needed to be self-reliance. Leebaert (1990) defined entrepreneurship as a process of organising, managing and assuming risk of a business enterprise. Omolayo (2006) opined that entrepreneurship is the act of starting a company, arranging business deals and taking risks in order to make a profit through the education skills acquired.Nwangwu (2007) opined that entrepreneurship is a process of bringing together the factors of production, which include land, labour and capital so as to provide a product or service for public consumption. The European commission as cited by Koko,Ikpesu, and Abayi,.(2009) defined entrepreneurship as 


\section{International Journal of Science and Research (IJSR) \\ ISSN (Online): 2319-7064 \\ Index Copernicus Value (2013): 6.14 | Impact Factor (2014): 5.611}

an individual's ability to turn ideas into action. It includes creativity, Innovation, risk-taking as well as the ability to plan and manage projects. This support everyone in day-today life at home and in society, employee in being aware of their work, being able to seize opportunities and is a Foundation for specific skills and knowledge needed by entrepreneurs Establishing social or commercial activity.

Entrepreneurship can be conceptualized as "the process of bringing together creative and innovative ideas and coupling these with management and organizational skills in order to combine people, money and resources to meet an identified need and create wealth. In the same vein, the operational definition of entrepreneurship is the willingness and ability of a person or persons to acquire educational skills to explore and exploit investment opportunities, establish and manage a successful business enterprise.

\section{Information \\ and \\ Communication Technology}

The term Information Technology(I.T or I.C.T) includes any equipment or interconnected system or subsystem of equipment, that is used in the automatic acquisition, storage, manipulation, management, movement, control, display, switching, interchange, transmission or reception of data or information.(Okurumeh 2012).

The most current ICT can be grouped into three (3) types,they are

- Information technologies with computers which has become an indispensible toolin modern societies to process data, save time and effort.

- Telecommunication technology which include telephone (fax), television, and satellites facilities.

- Network technology which is best known as internet, but which has extended to mobile phone technology (Okurumeh 2012).

- Akinpelu, Adewoyin and Otunla (1999) identified the following as the characteristics of information and communication Technology:

- Computer based technology can be adapted to meet particular needs

- Wide range of applications.

- Greater diversity of access.

- Declining cost.

- New media gives students greater control over their learning|training and greater interaction.

\section{ICT in Education}

Education is the chief agent for training the young for greater tomorrow and for socialization. Any nation in the 21st century that aspires to be developed must have means of imparting technological occupational skills in her students. On this basis, ICT education becomes a necessity to be pursued. It is acquired through computers and other electronic media. And with globalization and technological change as processes that have accelerated in tandem over the past fifteen years, it has created a new global economy "powered by technology, fuelled by information and driven by knowledge. U.S. Dept. of labour (1999). The emergence of this new global economy has serious implications for the nature and purpose of educational institutions. As the halflife of information continues to shrink and access to information continues to grow exponentially, schools cannot remain mere venues for the transmission of a prescribed set of information from teacher to student over a fixed period of time.Rather, schools must promote "learning to learn," That is, the acquisition of knowledge and skills that make possible continuous learning over the lifetime."The illiterate of the 21st century," according to futurist Alvin Toffler, "will not be those who cannot read and write, but those who cannot learn, unlearn, and relearn."Thornburg(1999).Concerns over educational relevance and quality coexist with the imperative of expanding educational opportunities to those made most vulnerable by globalization. That is, developing countries in general; low-income groups, girls and women, and lowskilled workers in particular. Information and communication technologies (ICTs), which include radio and television, as well as newer digital technologies such as computers and the Internet have been touted as potentially powerful enabling tools for educational change and reform. When used appropriately, different ICTs are can help to expand access to education, strengthen the relevance of education to the increasingly digital workplace, and raise educational quality by, among others, helping make teaching and learning into an engaging, active process connected to real life.

\section{Objectives of Entrepreneurship Education}

Entrepreneurship education according to Paul (2005) is structured to achieve the following objectives.

1) To offer functional education for the youth that will enable them to be self-employed and self-reliant.

2) Provide the young graduates or the individual with adequate training that will enable them to be creative and innovative in identifying novel business opportunities.

3) To serve as a catalyst for economic growth and development.

4) To reduce high rate of poverty.

5) Create employment generation.

6) Reduction in rural-urban migration.

7) Provide the young graduates/individual with enough training and support that will enable them to establish a career in small and medium sized businesses.

8) To inculcate the spirit of perseverance in the youths and adults which will enable them to persist in any business venture they embark on.

9) Create smooth transition from traditional to a modern industrial economy

\section{Problems of Putting Entrepreneurial Skills to Use in Nigeria}

Several problems have been identified by several authors and could be summarised as

- Poor electricity supply

- Unavailability of National ICT infrastructure.

- Insufficient qualified ICT personnel.

- Security problems.

- The preference of foreign made goods to made in Nigeria goods. 


\section{International Journal of Science and Research (IJSR) \\ ISSN (Online): 2319-7064}

Index Copernicus Value (2013): 6.14 | Impact Factor (2014): 5.611

- Poor funding.

- Inconsistency in government policies by successive government and

- Lack of political will on the part of the government of the day.

\section{Strategies for Effective Entrepreneurship Education in Information and Communication Technology (I.C.T)}

In order to achieve viable entrepreneurship education that will enhance sustainable development in Nigeria, the following strategies according to Ayodele (2006) will help to alleviate the problem of entrepreneurship education in the country:

1) There should be some form of genuine school work based learning incorporated in some studies as part of the national economic development strategies. The development of apprenticeship scheme would give the individual some work skills and experience.

2) Funds should be made available either as short or medium term loan.

3) School-based enterprises where students identify potential business, plan, create and operate small business using the school as mini-incubators.

4) Provide small business schools where interested students and community members can participate.

5) Develop entrepreneur internship programmes matching students with locally

Successful entrepreneurs with clearly established education programmes. That is, promoting public-private partnership in ICT entrepreneurial skills development

6) Establishing an enterprise college/ agency aimed at fostering the specific skills required for entrepreneurship to serve as skill acquisition centres for the youths.

7) Creating an economic friendly political environment.

8) Improving on the government taxation on small scale businesses.

Other areas where information and communication technology skills can be acquired are:

- Internet services

- Telecommunication services

a) Commercial mobile phone calls by individuals acquired through vocational training. This has made the youths to be self-employed and self reliant.

- Computer hardware repairs $\backslash$ maintenance and Sales of I.C.T products such as mobile handset, accessories, recharge cards etc.

- Software development.

b) Computer aided instruction (CAI) and computer aided learning" (CAL).

c) Programming.

d) Web site design

- Digital photography, film editing, etc using high definition equipment.

- Establishments of Computer training centres (Vocational Centres)

\section{Conclusion}

The modern world is by and large a man made world where learning skills is crucial for survival. Technological advancement has tremendously enhanced human capability. It has extended the senses and created possibilities never before imagined. Our modern day political clout, economic might and socio-cultural transformations are subject to and functions of our technological capability. Vocational education is a critical avenue through which such capability can be mastered, whether be in the formal or non-formal setting. We can only ignore it at our own detriment, more especially in Nigeria where unemployment rate is at an alarming proportion. This is liken to a time bomb that will consume all if adequate measures are not taken now. Hence, the potentials of ICT skills are needed to be harnessed. The recommendations should be taken seriously by all stakeholders to bring the needed economic development that Nigeria as a country badly need to eradicate abject poverty.

\section{Recommendations}

- Provision of quality education to all, especially in information and communication technology as the case may be.

- Entrepreneurship development starts and ends with the environment of vocational education, emphasis should be placed on the utilisation of vocational product to enhance national development through entrepreneurship.

- The Federal Government should embark on massive investments in the powerlenergy sector.

- Massive ICT infrastructural development should be embarked on and the establishment of vocational centres in the regions to train people in ICT related skills.

- Adequate security measures should be put in place to secure the investment from would-be investors and the ICT infrastructures that are likely to be put in place.

- Adequate funding, since poor funding and inconsistence in government policies has contributed in no small way in the underdevelopment of Nigeria.

- The rehabilitation of infrastructures and capacity building of institutions.

\section{References}

[1] Akinpelu, B, Adewoyin, B \&Otunla, K (1999) Fundamentals Of Media (design, Production And Utilisation) Lagos;Ziklag Educational Publishers.

[2] Aragba-Akpore, S. (1999).Major IT events of the year. The Guardian, Tuesday,January, 5

[3] Anthony. J. U,Saidu, A., Mohammed, M. \&Junguru, I. (2009). Developing Entrepreneurial Skills in Youths through Information and Communication Technology (ICT).Proceedings Of the $50^{\text {th }}$ Science Teachers Association Of Nigeria Annual National Conference. (STAN) pp. 232-236

[4] Ayodele, J.B. (2006).Obstacles to Entrepreneurship development in Nigeria.In F.Omotosho, T.K.O.Aluko, O.I. Wale-Awe and G. Adaramola (Eds).Introduction to Entrepreneurship Development in Nigeria.Ado-Ekiti, UNAD Press. 
[5] CBN(2014). Central Bank Of Nigeria News bulleting., June $6^{\text {th }} 2014$.

[6] Curtain, R. (2003).Creating More Opportunities For Young People Using Information And Communication Technology. The world summit on Information Societies, Geneva.

[7] Fafunwa.(1985). History of education in Nigeria.London: George Allen and Unwin.

[8] Federal Republic of Nigeria (FRN) (2015).National Policy on Education. Lagos, NERDC press

[9] Koko,,M.N,; Ikpesu,O.C and Abayi, T(2009).Promoting entrepreneurship culture through vocational education in Nigerian universities. Journal of the institute of education, vol. 4 (1) pp117.

[10]Leebaert, D (1990). Elements Entrepreneurship, Prosperity. Paper series.United States Information Agency.

[11] Meredith, O. (1983). The Practice of Entrepreneurship. Geneva: International Labour Office.

[12] Nwangwu, . O. (2007):Higher education for selfreliance: An imperative for the Nigerian Economy. NEAP publication pg. 1-8.

[13] Okurumeh, O.G.(2012). Introduction to computer studies 2Warri, COEWA publishers.

[14] Omolayo B. (2006). Entrepreneurship in Theory and Practice. In F. Omotosho, T.K.O. Aluko, O.I. Wale Awe and G. Adaramola (eds). Introduction to Entrepreneurship Development in Nigeria.AdoEkiti;UNAD Press.

[15] Paul, E.O. (2005).Entrepreneurship education in Ezema Priscilla N, Paul Elizabeth O.; Anioke Beatrice O., Godwin A.G. Okwuolise, Chikwe, A.Eheli, Henri U. Anih (Eds) Entrepreneurship in Vocational Education. Enugu: OZYBEL Publishers .

[16] Thornburg, David (2000), “Technology in K-12 Education: Envisioning a New Future"; available from http://www.air-dc.org/forum/abthornburg.htm.

[17] US Department of Labor (1999), Futurework-Trends and Challenges for Work in the 21st Century.Quoted in EnGauge,"21st Century Skills," North Central Regional Educational Laboratory; available from http://www.ncrel.org/engauge/skills/21skills.htm. 